UDC 94(47+57)“1943”:629.072.1

Submitted: 28.01.2019

LBC 63.3(2)622,12

Accepted: 24.04.2019

\title{
THE NAVIGATION OF 1943: THE BATTLE FOR THE VOLGA GOES ON
}

\author{
Olesya A. Gomanenko \\ Volgograd State University, Volgograd, Russian Federation
}

\begin{abstract}
Introduction. During the Second World War Volga ships suffered considerable losses from artillery fire and mines. Fighting for the Volga - the main waterway - continued even after the Battle of Stalingrad was over. The river was mined throughout 1943. The Volga way provided goods for the Front and back areas, includind oil, as before. Materials and methods. The study is based on the historism and objectivity principles and uses the general scientific as well as specific historical and statistical methods. The paper is based on published and unpublished archival materials as well as on scientific publications on the Volga Military Flotilla, the Volga crossings at Stalingrad, the Volga Steamship Lines and others. Analysis. The preparation for the navigation of 1943 was carried out under severe conditions when the waterway transportation facilities were being restored. The Volga Steamship Lines had suffered enormous material damage. Special agencies were created for salvaging and repair of sunken ships. The agencies included salvaging and repair squads. The Volga Military Flotilla was engaged in clearing the river of mines and wreckage. The Volga Military Flotilla ships kept escorting ship convoys as well. An integrated system for mining observation was organized on the Volga. Not only the Lower Volga was dangerous for navigation but also the Middle Volga. Results. The first period of the navigation of 1943 was characterized by slow movement of ships, mined waterway and air attack menace. During the second half of the navigation period the movement of ships was more intensive under relatively safe conditions. Shipping on the Volga became safer.

Key words: the Second World War, the Battle of Stalingrad, the Volga, restoration, river transport, mine risk, mine clearing, navigation.

Citation. Gomanenko O.A. The Navigation of 1943: The Battle for the Volga Goes On. Vestnik Volgogradskogo gosudarstvennogo universiteta. Seriya 4. Istoriya. Regionovedenie. Mezhdunarodnye otnosheniya [Science Journal of Volgograd State University. History. Area Studies. International Relations], 2019, vol. 24, no. 3, pp. 115125. (in Russian). DOI: https://doi.org/10.15688/jvolsu4.2019.3.10
\end{abstract}

УДК 94(47+57)“1943”:629.072.1

Дата поступления статьи: 28.01.2019

ББК 63.3(2)622,12

Дата принятия статьи: 24.04.2019

\section{НАВИГАЦИЯ 1943 ГОДА: БИТВА ЗА ВОЛГУ ПРОДОЛЖАЕТСЯ}

\section{Олеся Александровна Гоманенко}

Волгоградский государственный университет, г. Волгоград, Российская Федерация

\begin{abstract}
Аннотация. В годы Великой Отечественной войны от артиллерийских обстрелов и мин гибло большое количество волжских судов. Битва за Волгу как главную водную магистраль продолжалась и после завершения Сталинградского сражения. Минирование речной коммуникации продолжалось в течение 1943 года. Волга попрежнему обеспечивала доставку необходимых грузов для фронта и тыла, в том числе нефти. При этом требовалось увеличить объемы перевозок вследствие значительного разрушения железной дороги. Подготовка к навигации 1943 г. проходила в сложной обстановке восстановления водного хозяйства. Волжским речным пароходствам, особенно Нижневолжскому, был нанесен огромный материальный ущерб. Необходимо было поднять и отремонтировать больное количество судов. Помимо того, береговые сооружения Нижней Волги были почти полностью разрушены. Для подъема и восстановления потопленного флота организовывались специальные управления и их линейные подразделения, состоявшие из аварийно-судоподъемных и военновосстановительных отрядов. Силами моряков Волжской военной флотилии (ВВФ) проходило разминирование реки и расчистка ее фарватера от остатков погибших судов для безопасного движения судов. Кроме того, корабли ВВФ продолжали конвоировать караваны речного флота. На Волге организовывалась единая система
\end{abstract}


наблюдения за постановкой мин, состоявшая из наблюдательных постов ВВФ, противовоздушной обороны и бассейнового управления пути. Опасным участком для плавания была не только Нижняя, но и Средняя Волга. Таким образом, первый период навигации 1943 г. характеризовался медленным движением флота, наличием мин на фарватере и угрозой воздушных нападений противника. Во второй половине навигации флот двигался более интенсивно и в относительно спокойной обстановке. Судоходство на Волге стало более безопасным. С этого момента возросли перевозки, суда стали ходить с увеличенной нагрузкой.

Ключевые слова: Великая Отечественная война, Сталинградская битва, Волга, восстановление, речной транспорт, минная опасность, разминирование, навигация.

Цитирование. Гоманенко О. А. Навигация 1943 года: битва за Волгу продолжается // Вестник Волгоградского государственного университета. Серия 4, История. Регионоведение. Международные отношения. 2019. - T. 24, № 3. - C. 115-125. - DOI: https://doi.org/10.15688/jvolsu4.2019.3.10

Введение. Победное завершение Сталинградской битвы 2 февраля 1943 г. не означало завершения битвы за Волгу. Для работников речного флота и военных моряков Волжской военной флотилии (ВВФ) она завершилась только к концу навигации 1943 года. Подготовка к навигации проходила для пароходств Волги (Верхневолжского, Средневолжского, Нижневолжского, Волготанкера) в очень непростой обстановке. Работа речного флота в 1943 г. шла параллельно восстановительному процессу. Это требовало колоссальных материальных и людских затрат. Волга по-прежнему обеспечивала доставку необходимых грузов, как для фронта, так и для тыла. Вследствие значительного разрушения железной дороги требовалось увеличить объемы перевозок. При этом в течение 1943 г. продолжалось минирование реки. Безопасному судоходству также мешали затопленные суда. За годы Великой Отечественной войны от артобстрелов и мин погибло большое количество судов. Пострадал не только флот, но и береговые сооружения, особенно Нижней Волги.

Методы. Исследование базируется на принципах историзма и объективности с применением как общенаучных, так и специальных исторических методов. Использовались историко-сравнительный, историко-генетический, историко-системный, а также статистический методы. Статья основывается на изданных и неопубликованных архивных источниках. Историографию составили работы по исследованию деятельности Волжской военной флотилии [19], сталинградских переправ [22], речных пароходств в годы Великой Отечественной войны, в том числе вопросы восстановления волжской речной инфраструктуры $[1 ; 13 ; 15 ; 29]$ и др.
Анализ. По Нижневолжскому речному пароходству (НВРП) разному ремонту подлежали 156 единиц самоходного флота и 348 единиц несамоходного, причем флот оказался сильно рассредоточенным. Зимой 1942/43 гг. 203 судна НВРП находились в 58 ремонтных пунктах других пароходств (Московско-Окского, «Москва-Волга канал», Верхневолжского, Средневолжского, Камского, Бельского и Вятского). Остальной флот зимовал в 24 отстойных пунктах за пределами Нижней Волги и в 12 пунктах в границах Камышин Сталинград. Ремонт этих судов производился преимущественно силами судовых команд [8, л. 26 об.].

В подобной же ситуации находилось и пароходство «Волготанкер». В Астрахани на зимовке стояло 28 судов. В дельте Волги на реках Бузан и Васильевский банк - 11 судов, а в различных затонах между Сталинградом и Астраханью - еще 15. Остальной флот зимовал в отстойных пунктах выше Саратова и в Гурьеве. Так, в районе Гурьева находилось 65 судов и пять нефтемашинок [9, л. 8].

Текущий ремонт судов «Волготанкера» производился силами их команд. Минимальный ремонт был организован в отстойных пунктах. Срочный и сложный ремонт производился в Астрахани на заводе имени III Интернационала. Ремонт был организован также в Гурьеве и в отстойных пунктах на реке Урал. Для оказания помощи туда прибыли бригады с Астраханского судоремонтного завода им. В.И. Ленина, которые успешно работали вместе с судоремонтниками и плавсоставом Уральского пароходства. В самом Гурьеве в кратчайший срок был создан судоремонтный завод. Всего в межнавигационный период 1942/43 гг. на Гурьевском морском рейде и во 
льдах на р. Урал стояло свыше 1000 судов и кораблей «Волготанкера», «Рейдтанкера», НВРП, ВВФ и рыбной промышленности [2, c. 73,76$]$.

К началу навигации 1943 года пароходство Нижней Волги имело на своем балансе 544 ед. флота (без дебаркадеров), в том числе: самоходный флот - 179 ед., несамоходный флот - 365 ед. [13, с. 198]. «Волготанкер» начал навигацию 1943 г., имея 354 ед. флота, в том числе: самоходный флот - 153 ед., несамоходный флот - 201 ед. [9, л. 14-15].

Но новая навигация принесла новые проблемы, с которыми волжские пароходства раньше не сталкивались. Надо было заниматься еще и вопросами подъема и восстановления потопленного флота. В системах Народного комиссариата речного флота (НКРФ) и Народного комиссариата Военно-морского флота (НКВМФ) были организованы специальные управления и их линейные подразделения, состоявшие из аварийно-судоподъемных и военно-восстановительных отрядов. Однако из-за плохой организации работ по состоянию на 20 марта не достали ни одного судна (кроме трех, поднятых в 1942 г.). В районе Камышин - Сталинград - Владимировка первоочередного подъема ждали более 100 единиц, поскольку они лежали в фарватере Волги и создавали угрозу безопасности судоходства. Но и к лету 1943 г. план подъема судов не был выполнен [13, с. 67-68].

Помимо этого, в начале навигации 1943 г. Сталинградский порт не действовал, так как его причалы были заминированы. В это время шла работа воинских подразделений и специалистов Осоавиахима, а также самих речников по обезвреживанию взрывоопасных предметов. Только в мае стало возможным приступить к расчистке территорий порта и подходов к пристаням. После первичного разминирования береговых объектов НВРП количество грузоперевозок, в том числе нефтяных, стало возрастать [15, с. 121].

Между тем весной 1943 г. потребность промышленности в нефтепродуктах и других грузах резко возросла. Эвакуированные на восток заводы все более и более наращивали темпы выпуска военной продукции. Но железные дороги с Кавказа был перегружены и попрежнему подвергались опасности в силу сво- ей близкой расположенности к зоне боевых действий. Исключительное транспортное значение водного пути никуда не исчезло. В конце февраля Государственный Комитет Обороны (ГКО) потребовал у моряков и речников вывезти из Баку и отправить вверх по Волге из Астрахани 6,5 млн т нефтепродуктов. ЦК ВКП(б) и СНК СССР 18 апреля отправили телеграмму, адресованную секретарю Сталинградского обкома партии А.С. Чуянову, председателю Сталинградского облисполкома И.Ф. Зименкову и командующему ВВФ контр-адмиралу Д.Д. Рогачеву. Там указывалось на особое значение «Волготанкера» и НВРП в деле перевозки грузов и содержалось требование об оказании им всемерной поддержки [2, с. 75-76].

В целом, специалисты разделяли навигацию 1943 г. на два периода работы: до конца июля и с конца июля. Первый период характеризовался медленным движением флота, наличием мин на фарватере и угрозой воздушных нападений противника. Во второй половине навигации флот двигался более интенсивно и в более спокойной обстановке, но последствия Сталинградской битвы все же продолжали сказываться.

Еще 27 февраля 1943 г. для обеспечения противоминного и противовоздушного судоходства вводилось Положение об опасных районах и закрытых для плавания участках Волги [1, с. 103]. На Волжскую военную флотилию возлагалась задача по разминированию русла, с которой она полностью не справилась, вследствие чего открытие навигации затянулось [17, л. 30]. Хотя тральщики ВВФ приступили к работе сразу же после окончания весеннего ледохода, из-за их нехватки разминирование шло медленно [11, с. 57]. Для проводки флота были созданы пункты военно-лоцманской службы, где каждому судну выдавался путевой лист с отметками опасных для прохождения мест и закрытых фарватеров. Прохождение по непротраленным или обходным путям без лоцмана или тральщиков запрещалось [23].

С открытием навигации 1943 г. обстановка на Волге снова стала осложняться. 17 апреля самолеты противника начали воздушную разведку. С 28 апреля начались активные действия немецкой авиации по постановке мин на 
судовой ход и нападению на суда. При этом зона действия авиации даже расширилась по сравнению с периодом Сталинградской битвы, захватывая Волгу уже севернее Камышина. Минированию подвергся участок Волги протяженностью 800 км от села Замьяны (Астраханский округ) до села Золотое (Саратовская область). Цель противника оставалась прежней - прервать движение по ВолжскоКаспийскому пути, нанося главный удар по речным перевозкам. Вновь, как и в навигацию 1942 г., в дело вступило специальное подразделение немецких самолетов-миноносцев, которое базировалось на аэродромах в Донбacce $[2$, c. $78-79]$.

Эта новая угроза накладывалась на уже существовавшие. С 1942 г. в реке находилось около 130 необезвреженных мин. Кроме того, судовой ход был засорен останками затонувших судов. В первые месяцы навигации 1943 г. ширина судового хода была около 70 м. Пароходства «Рейдтанкер» и «Волготанкер» обязаны были сразу же отбуксировать поднятые суда в ремонтные пункты [26, л. 178].

Почти ежедневно на фарватер сбрасывались новые мины. Только за май 1943 г. на Волге было поставлено 354 мины, причем с точной ориентацией на судовой ход, так как действиям авиации в ночное время помогали освещенные знаки навигационного ограждения. Тральщики ВВФ просто не успевали разминировать фарватер. Для усиления постов воздушного наблюдения предусматривалось и привлечение гражданского населения прилегавших к реке районов [26, л. 178 об. - 179].

Судоводители старались обходить заминированные участки, частыми стали простои судов. Из-за закрытия движения в апреле и мае простои флота составили более $30 \%$ от всего эксплуатационного времени. Техническая скорость караванов снизилась на 40-70 \% $[9$, л. 9]. Кроме того, осложнилось продвижение флота в верховье реки. Это привело к большому скоплению судов на участке Сталинград - Астрахань.

Но движение на участке Астрахань Саратов не просто замедлилось. Снова появились жертвы. 23 апреля у Саралевского острова наскочил на старую мину и затонул пароход «Эривань» (капитан И.А. Трутнев). 2 мая на Солодниковском перекате на мине подорвался пароход «Сергей Лазо» (капитан Я.И. Краснов) [2, с. 79]. 7 мая от мин погибли нефтеналивные баржи «Катунь» и «Комсомолка», перевозившие 15700 т лигроина и автобензина. Одна из этих барж налетела на мину в 100 км ниже Сталинграда, другая - в 135 км выше [24, л. 122]. 13 мая на Светлоярском перекате подорвался и затонул нефтевоз «Ваня-коммунист» (капитан А.Ф. Панин), следовавший в Астрахань с баржей «Чулым» [2, с. 79-80].

С 28 апреля по 15 июня 1943 г. 18 судов подорвалось на минах [20, л. 45]. За этот период погибло более 16000 т нефтепродуктов $[34$, л. 6]. По разным данным, на участке Астрахань - Саратов за май было поставлено около 350 мин, из которых уничтожена лишь одна треть $[29$, с. $193 ; 30$, л. $83 ; 34$, л. 6].

Как и в 1942 г., в деле перевозок нефтепродуктов опять складывалось угрожающее положение. ГКО 9 мая 1943 г. потребовал от командования ВМФ и руководства речного транспорта безусловного выполнения плана нефтеперевозок. За три дня до этого нарком ВМФ адмирал Н.Г. Кузнецов был вызван в ГКО. Ему указали на то, что ВВФ не обеспечивает безопасности судоходства. Следовательно, получалось, что флотилия не обеспечивала в тот период и поставок горючего, крайне необходимого войскам в период подготовки к генеральному наступлению по всему фронту в 1943 году. По указанию ГКО нарком ВМФ сменил руководство флотилией. От контр-адмирала Д.Д. Рогачева командование перешло к контр-адмиралу Ю.А. Пантелееву [2, с. 81]. Было решено довести число тральщиков в районе Астраханский рейд Саратов до 300 единиц. Для этого по требованию НКВМФ в его распоряжение передавались 250 судов НКРФ и Наркомата рыбной промышленности, годных для переоборудования под тральщики. Эти суда отныне должны были всегда следовать перед нефтекараванами [24, л. 123].

Вновь было создано 424 специальных поста для наблюдения за вражескими самолетами и местами падения мин. С учетом же добровольцев количество точек наблюдения превысило 700. В свою очередь, корабли ВВФ рассредоточились по всей зоне ответственности. Весь участок Волги от Астрахани до 
Саратова был разбит на два весьма протяженных боевых района. Их общая протяженность составила 1164 км. Каждый район подразделялся на боевые участки (всего 8 участков). В центре каждого участка дислоцировался дивизион тральщиков. Участок от c. Замьяны до Астрахани, включая Астраханский морской рейд и Волго-Каспийский канал, был закреплен за тральными силами Астраханской военно-морской базы Каспийской военной флотилии. Чуть позже к восьми боевым участкам ВВФ (от Замьян до Саратова) добавился еще один - 9-й - участок. Это произошло уже во время битвы на Курской дуге, когда немецкая авиация сбросила бомбы на мосты у Сызрани. Опасным для плавания был объявлен участок от Саратова до пос. Батраки (Куйбышевская область) [19, с. 124, 156]. Таким образом, операционная зона ВВФ увеличилась на 333 км, протянувшись вдоль Волги на 1497 км. Увеличивалось и количество тральных сил.

Новому командующему ВВФ контр-адмиралу Ю.А. Пантелееву ГКО разрешил выдавать денежные премии лицам, отличившимся в деле обнаружения и уничтожения мин, сбрасываемых на Волгу. Премии устанавливались в размере от 1000 руб. за каждую обнаруженную мину до 5000 руб. за каждую уничтоженную мину [24, л. 124]. Появились новые системы освещения навигационного ограждения фарватера [2, с. 84].

Предпринимались и новые меры для охраны волжского пути от ударов с воздуха. Так, решением ГКО от 2 июня 1943 г. ответственность за противовоздушную оборону р. Волга от Астраханского рейда до Саратова была возложена на командующего ПВО страны генерал-лейтенанта М.С. Громадина. В самой системе ПВО за район от пристани Замьяны до Саратова стал отвечать командир Сталинградского корпусного района ПВО генерал-майор артиллерии Е.А. Райнин, а за район от пристани Замьяны до Астраханского рейда - командующий Астраханским бригадным районом полковник И.Ф. Морозов. В составе Сталинградского корпусного района к 10 июня 1943 г. предстояло сформировать две бригады ПВО. Одна бригада должна была прикрывать район Замьяны Райгород, а другая отвечала за район Райго- род - Саратов. В состав Астраханского бригадного района ПВО, отвечавшего за прикрытие р. Волга от пристани Замьяны до Астраханского рейда, решено было включить (дополнительно к уже имевшимся средствам ПВО) несколько полков истребительной авиации, малокалиберной зенитной артиллерии, зенитных пулеметов и пр. [25].

В результате предпринятых мер положение стало улучшаться. С 1 июня по 10 июля противнику удалось поставить на Волге только 45 мин (за май около 350). Корабли ВВФ проводили успешное траление фарватера (всего за 1942-1943 гг. моряками ВВФ была уничтожена 751 немецкая мина из 753, поставленных с начала боевых действий на Волге). Простои судов в ожидании открытия судовых ходов снизились с 809 часов в мае до 129 часов в июне. Пароходство «Волготанкер» получило от ВВФ 13 речных канонерских лодок, бывших буксирных пароходов, которые одновременно вели баржи с топливом и обеспечивали противовоздушную оборону. Отдельные рейды вражеских самолетов все же еще продолжались [2, с. 89, 167].

Тем не менее со второй половины июля речники работали уже в более спокойной обстановке. Судоходство на реке стало более безопасным. Ситуация на Волге улучшилась, возрастали перевозки, суда стали ходить с увеличенной нагрузкой. Постепенно набирал темпы вывоз нефтепродуктов. К осени 1943 г. по Волге прошло около 8000 судов, при этом ни одна нефтеналивная баржа с топливом не подорвалась на мине $[4$, с. 211,215$]$. Но минная опасность дала о себе знать в случае пассажирского теплохода «Карл Либкнехт» Верхневолжского речного пароходства (ВВРП). Он стал последней жертвой минной войны на Волге, подорвавшись 9 сентября 1943 г. в районе Старицкой воложки, в нижней части Крымского переката. Погибло много пассажиров и членов команды. Капитан Л.Н. Гудович был смертельно ранен [21, с. 405].

Общие итоги работы волжского флота за навигацию 1943 г. характеризовались следующими показателями. Нижневолжское речное пароходство вывезло свыше 1,4 млн т различных грузов (в 1942 г. - 1,0 млн т), а также перевезло почти 4,7 млн пассажиров. Объем перевозок НВРП 1943 г. составил половину от 
перевозок 1940 года. Однако мощность и грузоподъемность нижневолжского флота были намного меньше по сравнению с 1942 г. [12, c. 93-94]. Средневолжское речное пароходство (СВРП) в 1943 г. перевезло 3,1 млн т грузов [36, л. 9] (в 1942 г. - 3,4 млн т [6, л. 44 об.]) и 2,6 млн пассажиров [37, л. 15 об.] (в 1942 г. - 2,3 млн человек [7, л. 3]). За навигацию 1943 г. Верхневолжское речное пароходство отправило 5,6 млн т грузов [35, л. 45] (в 1942 г. - 5,1 млн т [6, л. 2-2 об.]). «Волготанкером» (при совместной работе с пароходством «Рейдтанкер») в 1943 г. было вывезено свыше 6,4 млн т нефтепродуктов (в том числе из Астрахани - 6,0 млн т) [9, л. 94].

Работников речного транспорта отметило руководство страны. 6 сентября 1943 г. Президиум Верховного Совета СССР издал Указ «О награждении работников Народного комиссариата речного флота СССР» [5, c. 178-185]. В 1947 г. совместным приказом Главного Штаба ВМС СССР и Министерства речного флота СССР на 39 судах, особо отличившихся в период битвы за Волгу, были установлены мемориальные доски [28, с. 21].

Победа в битве за Волгу была добыта ценой огромных жертв. Волжский флот понес тяжелые потери. Многие речники пали смертью храбрых. Пока точно установлено свыше 500 имен погибших [18, с. 165]. В навигацию 1942 г. суда гибли от бомб, мин, артиллерийского огня. В навигацию 1943 г. - от бомб и мин. Однако по количеству погибших судов до сих пор существуют различные данные. По одним данным, за обе навигации (главным образом - в 1942 г.) в районе Астрахань Саратов и на сталинградских переправах было потоплено 335 речных судов, а от 34 до 95 ед. получили серьезные повреждения [10, с. 65]. Из этих погибших судов волжских пароходств непосредственно в районе Сталинграда погибло 172 судна [22, с. 231]. По другим данным (данным Волгоградского народного музея речников), на Нижней Волге затонуло 389 судов, из них 244 судна погибло в границах города [2, с. 165].

Документы региональных и федеральных архивов также имеют разные данные. Следует заметить, что из-за противоречивости сведений невозможно установить точную цифру потерь. Кроме этого, не везде в доку- ментах разграничивается полностью и частично разрушенный флот. Многие потопленные суда потом были подняты и восстановлены. Однако можно определить общее число пострадавших судов. При сопоставлении всех данных за время Сталинградской битвы можно говорить о том, что пострадало около 430 волжских судов [16, л. 1-14; 27; 32, л. 96106; 33, л. 74-76 об.]. За период Сталинградской битвы пострадало большое количество не только нижневолжских судов, но и переброшенных на Нижнюю Волгу из других пароходств - Верхневолжского, Средневолжского, Камского, Шекснинского, Московско-Окского, Вятского, Северо-Западного, Бельского, «Волготанкера». Подавляющее большинство пострадавшего подвижного состава принадлежало НВРП (более 200 ед.), 25 судов СВРП, более 40 ед. ВВРП. Урон, нанесенный непосредственно флоту СВРП и НВРП, достигал 83109700 руб., причем две трети приходилось на НВРП. В результате военных действий серьезно пострадала и погибла, по разным сведениям, четверть баланса НВРП [14]. В целом размер общих потерь по Средневолжскому и Нижневолжскому пароходствам составил 7,4\% (1 715450601 руб.) от общего ущерба, причиненного НКРФ [31, л. 8, 10, 16]. Общий размер ущерба включал в себя как восстановительную стоимость полностью уничтоженного имущества, так и затраты для восстановления частично поврежденного. Так, по НВРП это в пять раз больше, чем по СВРП. По одним данным размер урона НВРП составлял 104,3 млн руб., по другим - 114 млн руб. [3, с. 49].

ВВФ потеряла 24 корабля (4 бронекатеpa, 14 тральщиков, 6 полуглиссеров). Из них на переправах в Сталинграде - 18 кораблей. Кроме того, погибло более 70 единиц переправочных средств инженерных войск: паромов СП-19 - 7 единиц, катеров БМК-70 9 единиц, катеров С-25 - 4 единицы, лодок разных - более 25 единиц, полупонтонов - 35 единиц [22, с. 231].

Результаты. Таким образом, за годы войны волжской речной инфраструктуре был нанесен большой материальный урон. Даже после завершения Сталинградской битвы на протяжении 1943 г. продолжалось минирование и обстрел Волги. Опасным участком для плавания была не только Нижняя, но и Сред- 
няя Волга. Первый период навигации 1943 г. характеризовался медленным движением флота, наличием мин и угрозой воздушных нападений. Во второй половине навигации флот двигался более интенсивно и в относительно спокойной обстановке. Судоходство на Волге стало более безопасным. С этого момента возросли перевозки. Несмотря ни на что, противнику так и не удалось нарушить волжскую водную коммуникацию. Битва за Волгу была выиграна.

\section{СПИСОК ЛИТЕРАТУРЫ}

1. Амусин, Б. М. Использование речного транспорта на фронтовых речных и озерных бассейнах в Великой Отечественной войне 1941-1945 гг. / Б. М. Амусин. - Калининград : Типография Калининградского ВВМУ, 1997. - 202 с.

2. Битва за нефть : Речники «Волготанкера» в битве за нефть, за Волгу и обороне Сталинграда (неопубликованная рукопись ветеранов пароходства «Волготанкер»). - Куйбышев, 1985. - 229 с.

3. Булатов, В. В. Экономическая история России (от июня 1941 года до сентября 1953 года) : учеб. пособие / В. В. Булатов, О. А. Гоманенко. - Волгоград : Волгогр. науч. изд-во, 2016. - 82 c.

4. Булатов, В.Н. Адмирал Кузнецов / В.Н. Булатов. - М. : Воениздат, 2009. - 384 с.

5. Волгари в боях за Сталинград. - Сталинград : Сталинград. кн. изд-во, 1961. - 186 с.

6. Годовой отчет об отправленных грузах по НКРФ за 1942 г. // Российский государственный архив экономики (РГАЭ). - Ф. 9469. - Оп. 2. - Д. 22.

7. Годовой отчет об отправленных пассажирах НКРФ за 1942 г. // РГАЭ. - Ф. 9469. Оп. 2. - Д. 23.

8. Годовой отчет об эксплуатационной деятельности НВРП за 1942 г. // РГАЭ. - Ф. 9469. Оп. 6. - Д. 26.

9. Годовой эксплуатационный отчет пароходства «Волготанкер» за навигацию 1943 года // Центральный государственный архив Самарской области. - Ф. Р-4139. - Оп. 1. - Д. 53.

10. Гоманенко, О. А. Восстановление материально-технической базы речной инфраструктуры Нижней Волги в 1943 году / О. А. Гоманенко // Экономическая история России: проблемы, поиски, решения : ежегодник. - Вып. 10. - М. ; Волгоград : Изд-во ВолГУ, 2008. - С. 65-70.

11. Гоманенко, О. А. Минная опасность на Нижней Волге в навигацию 1943 года / О. А. Гоманенко, О. Ю. Редькина // Проблемы национальной безопасности России: уроки истории и вызовы со- временности. 25 лет без Советского Союза : материалы Междунар. науч.-просветительской конф., 27-31 мая 2016 г. - Краснодар : Традиция, 2016. C. $56-60$.

12. Гоманенко, О. А. Нижневолжское речное пароходство в 1943 г. / О. А. Гоманенко // Экономическая история России: проблемы, поиски, решения : ежегодник. - Вып. 7. - М. ; Волгоград : Изд-во ВолГУ, 2005. - С. 91-95.

13. Гоманенко, О. Нижневолжское речное пароходство в Великой Отечественной войне, 19401945 гг. / О. Гоманенко. - Saarbrücken : LAP LAMBERT Academic Publishing, 2011. - 256 c.

14. Гоманенко, О. А. Новые данные о потерях речного флота в ходе Сталинградской битвы / О. А. Гоманенко // Стрежень : Научный ежегодник. Вып. 3. - Волгоград : Изд-во ВолгГУ, 2003. C. 293-321.

15. Гоманенко, О. А. Первоочередные мероприятия по восстановлению Сталинграда и области после окончания сражения на Волге / О. А. Гоманенко // Вестник Волгоградского государственного университета. Серия 4, История. Регионоведение. Международные отношения. - 2018. - Т. 23, № 1. - С. 116-125. DOI: https://doi.org/10.15688/jvolsu4.2018.1.11.

16. Данные Волго-Доно-Кубанского Управления судоподъемных и аварийно-спасательных работ «Список судов, затонувших в 1942 г., с указанием технических данных, места и причины аварии» // Государственный архив Волгоградской области (ГАВО). - Ф. 2631. - Оп. 1. - Д. 45.

17. Докладная записка секретарю Сталинградского ОК ВКП(б) т. А.С. Чуянову от начальника водного отделения НКВД т. Красова «О подготовке НВРП к навигации 1943 г.», 23 марта 1943 г. // Центр документации новейшей истории Волгоградской области (ЦДНИВО). - Ф. 113. - Оп. 14. - Д. 162. Л. 30-33.

18. Книга памяти : в 3 т. - Волгоград : Издатель, 2004. - Т. 3 : Поименный список (доп.). - 248 с.

19. Локтионов, И. И. Волжская флотилия в Великой Отечественной войне / И. И. Локтионов. - М. : Воениздат, 1974. - 182 c.

20. Оперативная справка Председателю СГКО т. А.С. Чуянову и секретарю Сталинградского ОК ВКП(б) из штаба ВВФ «О боевой деятельности ВВФ за период с 23 апреля по 15 июня 1943 г.» // ЦДНИВО. - Ф. 171. - Оп. 1. - Д. 148. - Л. 44-45.

21. Пермяков, В. Опаленные Волгой / В. Пермяков. - Самара : Данглис, 2002. -449 с.

22. Плехов, И. М. В огне сталинградских переправ / И. М. Плехов, С. П. Хватов, Г. И. Захаров. 3-е изд. - Волгоград : Издатель, 2001. -272 с.

23. Положение о военно-лоцманской службе ВВФ в опасных районах р. Волги, 1943 г. // ЦДНИВО.Ф. 11418. - Оп. 1.- Д. 26. - Л. 62-63. 
24. Постановление ГКО № 3336с от 9 мая 1943 г. «Об обеспечении перевозок нефтепродуктов от Астраханского рейда до Саратова» // Российский государственный архив социально-политической истории (РГАСПИ). - Ф. 644. - ОП. 2. - Д. 168. Л. 122-125.

25. Постановление ГКО № 3488сс от 2 июня 1943 г. «О дополнительных мероприятиях по противовоздушной обороне р. Волги от Астраханского рейда до г. Саратова» // РГАСПИ. - Ф. 644. Оп. 2. - Д. 175. - Л. 132-133.

26. Протокол № 206 заседания бюро Сталинградского ОК ВКП(б) от 11 мая 1943 г. «Об обеспечении нефтеперевозок пароходствами "Волготанкер" и “Рейдтанкер”» // ЦДНИВО. - Ф. 113. - Оп. 14. Д. 5. - Л. 177 об. -179.

27. Реестры, обобщенные сведения и акты по учету ущерба, причиненного немецко-фашистскими захватчиками, хозяйству пароходств и Управлений пути Волжского бассейна НКРФ СССР, 19431944 г. // Государственный архив Российской Федерации (ГАРФ). - Ф. 7021. - Оп. 2. - Д. 353. - Л. 234 237 об.

28. Речники в обороне Царицына и в Великой Сталинградской битве. - Волгоград : Нижне-Волжское книжное издательство, 1967. - 78 с.

29. Речной транспорт за 50 лет Советской власти. - М. : Транспорт, 1967. - 336 с.

30. Сводка зам. начальника управления пароходства «Волготанкер» т. Сухарина о положенных и уничтоженных минах в результате действия вражеской авиации за время с 1 мая по 1 июня навигации 1943 г. // ЦДНИВО. - Ф. 113. - Оп. 12. - Д. 129. Л. 83-83 об.

31. Сводный отчет по учету ущерба, причиненного немецко-фашистскими захватчиками и их сообщниками, хозяйству НКРФ СССР, 1944 г. // ГАРФ. Ф. 7021. - Оп. 2. - Д. 356.

32. Список зам. начальника МВКЦУРФ т. Чернова с перечнем судов Волжского флота, пострадавшего от военных действий, 15 февраля 1944 г. // ГАВО. - Ф. 5513. - Оп. 2. - Д. 4. - Л. 96-106.

33. Список погибшего и поврежденного флота на участке Астрахань - Саратов, 1942 г. // ГАВО. Ф. 5513. - Оп. 2. - Д. 4. - Л. 74-76 об.

34. Справка об итогах навигации по нефтеперевозкам в навигацию 1943 г. и подготовке к навигации 1944 г. // ЦДНИВО. - Ф. 113. - Оп. 14. Д. 161. -Л. 4-6.

35. Эксплуатационный отчет ВВРП за навигацию 1943 г. Т. 1 // РГАЭ. - Ф. 9469. - Оп. 6. Д. 44.

36. Эксплуатационный отчет СВРП за 1943 г. // РГАЭ. - Ф. 9469. - Оп. 6. - Д. 46.

37. Эксплуатационный отчет СВРП за 1944 г. // РГАЭ. - Ф. 9469. - Оп. 6. - Д. 71.

\section{REFERENCES}

1. Amusin B.M. Ispolzovanie rechnogo transporta na frontovykh rechnykh i ozernykh basseynakh $v$ Velikoy Otechestvennoy voyne 1941$1945 \mathrm{gg}$. [Use of River Transport on Front River and Lake Basins in the Great Patriotic War. 1941-1945]. Kaliningrad, Tipografiya Kaliningradskogo VVMU Publ., 1997. 202 p.

2. Bitva za neft: Rechniki «Volgotankera» v bitve za neft, za Volgu i oborone Stalingrada (neopublikovannaya rukopis veteranov parokhodstva "Volgotanker») [The Battle for Oil: The Rivermen of "Volgotanker" in the Battle for Oil, the Volga and the Defense of Stalingrad (Unpublished Manuscript of Veterans of "Volgotanker" Steamship Line)]. Kuybyshev, 1985.229 p.

3. Bulatov V.V., Gomanenko O.A. Ekonomicheskaya istoriya Rossii (ot iyunya 1941 goda do sentyabrya 1953 goda): uchebnoe posobie [Economic History of Russia (From June, 1941 to September, 1953): Study Guide]. Volgograd, Volgogradskoe nauchnoe izd-vo, 2016. $82 \mathrm{p}$.

4. Bulatov V.N. Admiral Kuznetsov. Moscow, Voenizdat, 2009. 384 p.

5. Volgari $v$ boyakh za Stalingrad [Volga Workers in the Battles for Stalingrad]. Stalingrad, Stalingradskoe knizhnoe izd-vo, 1961. 186 p.

6. Godovoy otchet ob otpravlennykh gruzakh po NKRF za 1942 g. [Annual Report on Shipped Cargos According to the People's Commissariat of River Fleet for 1942]. Rossiyskiy gosudarstvennyy arkhiv ekonomiki [Russian State Archive of Economy], F. 9469, Op. 2, D. 22.

7. Godovoy otchet ob otpravlennykh passazhirakh NKRF za 1942 g. [Annual Report on Shipped Passengers According to the People's Commissariat of River Fleet for 1942]. Rossiyskiy gosudarstvennyy arkhiv ekonomiki [Russian State Archive of Economy], F. 9469, Op. 2, D. 23.

8. Godovoy otchet ob ekspluatatsionnoy deyatelnosti NVRP za 1942 g. [Annual Report on Operational Activities of the Lower Volga Steamship Line in 1943]. Rossiyskiy gosudarstvennyy arkhiv ekonomiki [Russian State Archive of Economy], F. 9469, Op. 6, D. 26.

9. Godovoy ekspluatatsionnyy otchet parokhodstva «Volgotanker» za navigatsiyu 1943 goda [Annual Report on Operational Activities of "Volgotanker" Steamship Line for the Navigation of 1943]. Tsentralnyy gosudarstvennyy arkhiv Samarskoy oblasti [Central State Archive of Samara Region], F. R-4139, Op. 1, D. 53.

10. Gomanenko O.A. Vosstanovlenie materialnotekhnicheskoy bazy rechnoy infrastruktury Nizhney Volgi v 1943 godu [Reconstruction of the Material and Technical Basis of the Lower Volga Transport 
Infrastructure in 1943]. Ekonomicheskaya istoriya Rossii: problemy, poiski, resheniya: ezhegodnik [Economic History of Russia. Problems, Searches, Solutions. Year-Book]. Moscow, Volgograd, Izd-vo VolGU, 2008, iss. 10, pp. 65-70.

11. Gomanenko O.A., Redkina O.Yu. Minnaya opasnost na Nizhney Volge v navigatsiyu 1943 goda [The Mine Threat in the Lower Volga During the Navigation of 1943]. Problemy natsionalnoy bezopasnosti Rossii: uroki istorii $i$ vyzovy sovremennosti. 25 let bez Sovetskogo Soyuza: materialy Mezhdunar. nauch.prosvet. konf., 27-31 maya 2016 g. [Russian National Security Issues. Lessons of History and Modern Challenges. 25 Years Without the Soviet Union. Proceedings of the International Theoretical and Educational Conference, May 27-31, 2016]. Krasnodar, Traditsiya Publ., 2016, pp. 56-60.

12. Gomanenko O.A. Nizhnevolzhskoe rechnoe parokhodstvo v 1943 g. [The Lower Volga River Steamship Line in 1943]. Ekonomicheskaya istoriya Rossii: problemy, poiski, resheniya: ezhegodnik [Economic History of Russia. Problems, Searches, Solutions. Year-Book]. Moscow, Volgograd, Izd-vo VolGU, 2005, iss. 7, pp. 91-95.

13. Gomanenko O. Nizhnevolzhskoe rechnoe parokhodstvo $v$ Velikoy Otechestvennoy voyne, 1940 $1945 \mathrm{gg}$. [Lower Volga River Steamship Line in the Great Patriotic War. 1940-1945]. Saarbrücken, LAP LAMBERT Academic Publishing, 2011.256 p.

14. Gomanenko O.A. Novye dannye o poteryakh rechnogo flota $\mathrm{v}$ khode Stalingradskoy bitvy [New Data on Losses of the River Fleet During the Battle of Stalingrad]. Strezhen: Nauchnyy ezhegodnik [Annual "Strezhen"]. Volgograd, Izd-vo. VolGU, 2003, iss. 3, pp. 293-321.

15. Gomanenko O.A. Pervoocherednye meropriyatiya po vosstanovleniyu Stalingrada i oblasti posle okonchaniya srazheniya na Volge [Priority Measures on the Restoration of Stalingrad and the Region After the End of the Battle on the Volga]. Vestnik Volgogradskogo gosudarstvennogo universiteta. Seriya 4. Istoriya. Regionovedenie. Mezhdunarodnye otnosheniya [Science Journal of Volgograd State University. History. Area Studies. International Relations], 2018, vol.23, no. 1, pp. 116-125. DOI: https:/ /doi.org/10.15688/jvolsu4.2018.1.11.

16. Dannye Volgo-Dono-Kubanskogo Upravleniya sudopodemnykh i avariyno-spasatelnykh rabot «Spisok sudov, zatonuvshikh v 1942 g., s ukazaniem tekhnicheskikh dannykh, mesta i prichiny avarii» [Data of the Volga-Don-Kuban Department of Ship-Raising and Rescue Operations "The List of Ships Which Went down in 1942, with Technical Data, Location and Cause of the Accident"]. Gosudarstvennyy arkhiv Volgogradskoy oblasti [State Archive of Volgograd Region], F. 2631, Op. 1, D. 45.
17. Dokladnaya zapiska sekretaryu Stalingradskogo OK VKP(b) t. A.S. Chuyanovu ot nachalnika vodnogo otdeleniya NKVD t. Krasova «O podgotovke NVRP k navigatsii 1943 g.», 23 marta 1943 g. [Report to Secretary of Stalingrad Regional Committee of the All-Union Communist Party (Bolsheviks) c. A.S. Chuyanov of Head of the Water Department NKVD c. Krasov "About the Preparation of the Lower Volga Steamship Line for the Navigation of 1943. March 23, 1943"]. Tsentr dokumentatsii noveyshey istorii Volgogradskoy oblasti (TsDNIVO) [The Center of Modern History Documentation of Volgograd Region], F. 113, Op. 14, D. 162, L. 30-33.

18. Kniga pamyati: $v 3$ t. T. 3. Poimennyy spisok (dop.) [Book of Memory. In 3 vols. Vol. 3. List of Names (Add.)]. Volgograd, Izdatel Publ., 2004. 248 p.

19. Loktionov I.I. Volzhskaya flotiliya v Velikoy Otechestvennoy voyne [The Volga Military Flotilla in the Great Patriotic War]. Moscow, Voenizdat, 1974. 182 p.

20. Operativnaya spravka Predsedatelyu SGKO t. A.S. Chuyanovu i sekretaryu Stalingradskogo OK VKP(b) iz shtaba VVF «O boevoy deyatelnosti VVF za period s 23 aprelya po 15 iyunya 1943 g.» [Operational Reference to Chairman of Stalingrad City Defense Committee c. A.S. Chuyanov and the Secretary of Stalingrad Regional Committee of the All-Union Communist Party (Bolsheviks) from the Volga Military Flotilia Headquarters “About the Military Activity of the Volga Military Flotilia for the Period from April 23 to June 15, 1943"]. Tsentr dokumentatsii noveyshey istorii Volgogradskoy oblasti (TsDNIVO) [The Center of Modern History Documentation of Volgograd Region], F. 171, Op. 1, D. 148, L. 44-45.

21. Permyakov V. Opalennye Volgoy [Scorched by the Volga]. Samara, Danglis Publ., 2002. 449 p.

22. Plekhov I.M., Khvatov S.P., Zakharov G.I. Vogne stalingradskikh pereprav [In the Fire of Stalingrad Crossings]. Volgograd, Izdatel Publ., 2001. 272 p.

23. Polozhenie o voenno-lotsmanskoy sluzhbe VVF v opasnykh rayonakh r. Volgi. 1943 g. [Regulation on the Military Pilot Service of the Volga Military Flotilia in Dangerous Areas of the Volga River. 1943]. Tsentr dokumentatsii noveyshey istorii Volgogradskoy oblasti (TsDNIVO) [The Center of Modern History Documentation of Volgograd Region], F. 11418, Op. 1, D. 26, L. 62-63.

24. Postanovlenie GKO № 3336s ot 9 maya 1943 g. «Ob obespechenii perevozok nefteproduktov ot Astrakhanskogo reyda do Saratova» [Resolution of the State Defense Committee no. 3336c of May 9, 1943 "On Ensuring the Transportation of Oil Products from Astrakhan Raid to Saratov"]. Rossiyskiy gosudarstvennyy arkhiv sotsialno-politicheskoy istorii (RGASPI) [Russian State Archive of Social and Political History], F. 644, Op. 2, D. 168, L. 122-125. 
25. Postanovlenie GKO № 3488ss ot 2 iyunya 1943 g. «O dopolnitelnykh meropriyatiyakh po protivovozdushnoy oborone r. Volgi ot Astrakhanskogo reyda do g. Saratova» [Resolution of the State Defense Committee no. 3488cc of June 2, 1943 "On Additional Measures on Air Defense of the River Volga from the Astrakhan Raid to Saratov"]. Rossiyskiy gosudarstvennyy arkhiv sotsialnopoliticheskoy istorii (RGASPI) [Russian State Archive of Social and Political History], F. 644, Op. 2, D. 175, L. 132-133.

26. Protokol № 206 zasedaniya byuro Stalingradskogo OK VKP(b) ot 11 maya 1943 g. «Ob obespechenii nefteperevozok parokhodstvami "Volgotanker" i "Reydtanker"» [Record no. 206 of the Bureau of the Stalingrad Regional Committee of the All-Union Communist Party (Bolsheviks) of May 11, 1943 "On Providing Oil Transportation by "Volgotanker" and "Reidtanker" Steamship Lines"]. Tsentr dokumentatsii noveyshey istorii Volgogradskoy oblasti (TsDNIVO) [The Center of Modern History Documentation of Volgograd Region], F. 113, Op. 14, D. 5, L. 177 ob.-179.

27. Reestry, obobshchennye svedeniya i akty po uchetu ushcherba, prichinennogo nemetskofashistskimi zakhvatchikami, khozyaystvu parokhodstv i Upravleniy puti Volzhskogo basseyna NKRF SSSR, 1943-1944 g. [Registers, Generalized Data and Acts on Accounting Damage Caused by Fascist Aggressors to the Economy of Steamship Lines and Way Managements of the Volga Basin of People's Commissariat of the River Fleet of the USSR. 19431944]. Gosudarstvennyy arkhiv Rossiyskoy Federatsii [State Archive of the Russian Federation], F. 7021, Op. 2, D. 353, L. 234-237 ob.

28. Rechniki v oborone Tsaritsyna $i v$ Velikoy Stalingradskoy bitve [Rivermen in the Defense of Tsaritsyn and in the Great Battle of Stalingrad]. Volgograd, Nizhne-Volzhskoe knizhnoe izd-vo, 1967.78 p.

29. Rechnoy transport za 50 let Sovetskoy vlasti [River Transport for 50 Years of Soviet Power]. Moscow, Transport Publ., 1967.336 p.

30. Svodka zam. nachalnika upravleniya parokhodstva «Volgotanker» t. Sukharina o polozhennykh i unichtozhennykh minakh $\mathrm{v}$ rezultate deystviya vrazheskoy aviatsii za vremya s 1 maya po 1 iyunya navigatsii 1943 g. [Report of Deputy Head of "Volgotanker" Steamship Line c. Sukharin on Laid and Destroyed Mines as a Result of Enemy Aircraft During the Period of the Navigation from May 1 to June 1, 1943]. Tsentr dokumentatsii noveyshey istorii
Volgogradskoy oblasti (TsDNIVO) [The Center of Modern History Documentation of Volgograd Region], F. 113, Op. 12, D. 129, L. 83-83 ob.

31. Svodnyy otchet po uchetu ushcherba, prichinennogo nemetsko-fashistskimi zakhvatchikami i ikh soobshchnikami, khozyaystvu NKRF SSSR. 1944 g. [Summary Report on Accounting Damage Caused by Fascist Aggressors and Their Accomplices, to Economy of the People's Commissariat of the River Fleet of the USSR. 1944]. Gosudarstvennyy arkhiv Rossiyskoy Federatsii [State Archive of the Russian Federation], F. 7021, Op. 2, D. 356.

32. Spisok zam. nachalnika MVKTsURF t. Chernova s perechnem sudov Volzhskogo flota, postradavshego ot voennykh deystviy. 15 fevralya 1944 g. [The List of Deputy Chief of Moscow-Volga-Kama Central Administration of the River Fleet c. Chernov with the List of Vessels of the Volga Fleet Affected by Military Operations. February 15, 1944]. Gosudarstvennyy arkhiv Volgogradskoy oblasti [State Archive of Volgograd Region], F. 5513, Op. 2, D. 4, L. 96-106.

33. Spisok pogibshego i povrezhdennogo flota na uchastke Astrakhan - Saratov, $1942 \mathrm{~g}$. [The List of the Dead and Damaged Fleet in the Area of Astrakhan - Saratov. 1942]. Gosudarstvennyy arkhiv Volgogradskoy oblasti [State Archive of Volgograd Region], F. 5513, Op. 2, D. 4, L. 74-76 ob.

34. Spravka ob itogakh navigatsii po nefteperevozkam v navigatsiyu $1943 \mathrm{~g}$. i podgotovke $\mathrm{k}$ navigatsii $1944 \mathrm{~g}$. [Information About the Results of Navigation on Oil Transportation During the Navigation of 1943 and Preparation for Navigation in 1944]. Tsentr dokumentatsii noveyshey istorii Volgogradskoy oblasti (TsDNIVO) [The Center of Modern History Documentation of Volgograd Region], F. 113, Op. 14, D. 161, L. 4-6.

35. Ekspluatatsionnyy otchet VVRP za navigatsiyu 1943 g. T. 1 [Operational Report of the Upper Volga Steamship Line for the Navigation of 1943. Vol. 1]. Rossiyskiy gosudarstvennyy arkhiv ekonomiki [Russian StateArchive ofEconomy], F. 9469, Op. 6, D. 44.

36. Ekspluatatsionnyy otchet SVRP za 1943 g. [Operational Report of the Middle Volga Steamship Line for 1943]. Rossiyskiy gosudarstvennyy arkhiv ekonomiki [Russian State Archive of Economy], F. 9469, Op. 6, D. 46.

37. Ekspluatatsionnyy otchet SVRP za 1944 g. [Operational Report of the Middle Volga Steamship Line for 1944]. Rossiyskiy gosudarstvennyy arkhiv ekonomiki [Russian State Archive of Economy], F. 9469, Op. 6, D. 71. 


\section{Information about the Author}

Olesya A. Gomanenko, Candidate of Sciences (History), Associate Professor, Department of Social Technologies, Volgograd State University, Prosp. Universitetsky, 100, 400062 Volgograd, Russian Federation, gomanenko@volsu.ru, gomanenko.olesya@mail.ru, https://orcid.org/0000-0001-9178-1145

\section{Информация об авторе}

Олеся Александровна Гоманенко, кандидат исторических наук, доцент кафедры социальных технологий, Волгоградский государственный университет, просп. Университетский, 100, 400062 г. Волгоград, Российская Федерация, gomanenko@volsu.ru, gomanenko.olesya@mail.ru, https://orcid.org/0000-0001-9178-1145 